\title{
STRATEGY OF TOURISM DEVELOPMENT AFTER COVID-19 PANDEMIC: RUSSIAN CASE
}

\author{
Larisa DESFONTEINES ${ }^{1}$; Elena KORCHAGINA ${ }^{1}$; Natalia STREKALOVA ${ }^{2}$ \\ ${ }^{1}$ Peter the Great St. Petersburg Polytechnic University, Institute of Industrial Management, \\ Economics and Trade, Graduate School of Service and Trade \\ ${ }^{2}$ Herzen State Pedagogical University of Russia
}

\begin{abstract}
The covid-19 pandemic affected all areas of the economy including tourism sector. In the tourism sector, the epidemic has led to a deep crisis associated with the closure of borders. The consequences will lead to significant changes in the directions of tourism and the forms of interaction with consumers of services.

Purpose: The main goal of the study is to identify new directions of domestic tourism in Russia after the removal of restrictions related to the covid-19 epidemic and to identify prospects for the development of tourism for the subjects of the Russian tourist market.

Design/methodology/approach: The study used data from legislative acts of the Russian Federation, the Russian Public Opinion Research Center (VCIOM) data of opinion polls, scientific and practical periodicals on the development of the tourism industry.

Findings The crisis of the tourism industry has changed the strategy of tourism development in Russia. The players of the tourism industry market have to apply the advanced development strategy. The main directions of tourism development in Russia after the Covid-19 pandemic crisis are following: the development of new, innovative areas of domestic tourism; budget domestic routes, focusing on particular age groups and healthy lifestyle activities, increasing use of digital technologies in the both promotion and support of tourist products.

Practical implications: The comparative analysis of the preferences of Russian citizens in the tourism field allows creating the new strategy, forming new products and developing new directions in the tourism industry.
\end{abstract}

Key words: tourism, tourist products, consumers, preferences, strategy.

\section{Introduction}

The tourism sector of the world economy accounts for about $10 \%$ of GDP. On the one hand, tourism is a catalyst for the development of various sectors of the country's economy, on the other hand, tourism is a vulnerable area of business. Changes in the economic situation, political events can act as conditions that hinder the tourism development as well as all the related areas. In the tourism sector, the Covid-19 pandemic has led to a deep crisis caused by the lockdowns and border closures. The consequences of the crisis will lead to significant changes in the priority areas in tourism and forms of interaction with consumers of the tourism services. Competition in this area will move to a different level, which will lead to a completely new distribution of resources in this market.

The statistical bulletin of the Rosstat, published on the occasion of the World Tourism Day, reflected the importance of the tourism industry in the both world and

https://doi.org/10.11118/978-80-7509-820-7-0418

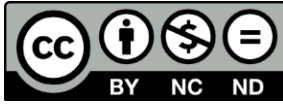


Russian GDPs. The data is shown in Figure 1. In addition, before the Covid-19 pandemic, a tenth of the world's working-age population worked in this industry.

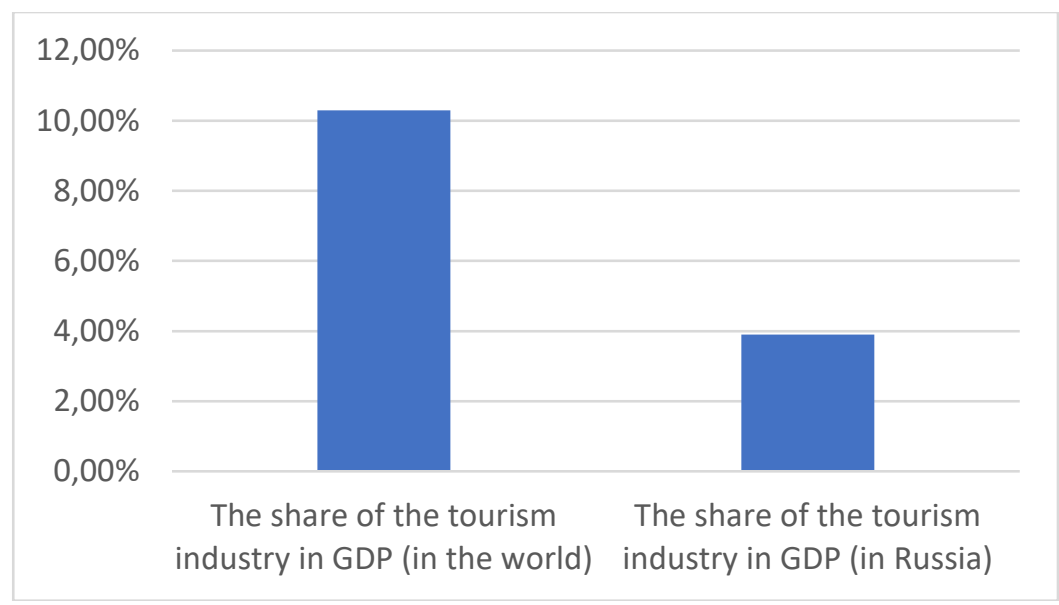

Figure 1. The share of tourism in world and Russian GDPs (Rosstat Statistical Bulletin for the World Tourism Day 2020. https://www.cci.lt/wpcontent/uploads/2020/10)

As shown in Figure 1, tourism accounted for 10.3\% of global GDP in 2017-18. For Russia, this share was $3.9 \%$, which is $0.9 \%$ higher than in the US, UK and Australia (rosstat.gov.ru). Due to restrictions related to the Covid-19 pandemic in 2020, international tourism was reduced by $95.2 \%$ in the world, $99,0 \%$ in Russia, 95,8\% in the US, $99.1 \%$ in Spain, $100 \%$ in Thailand (rosstat.gov.ru).

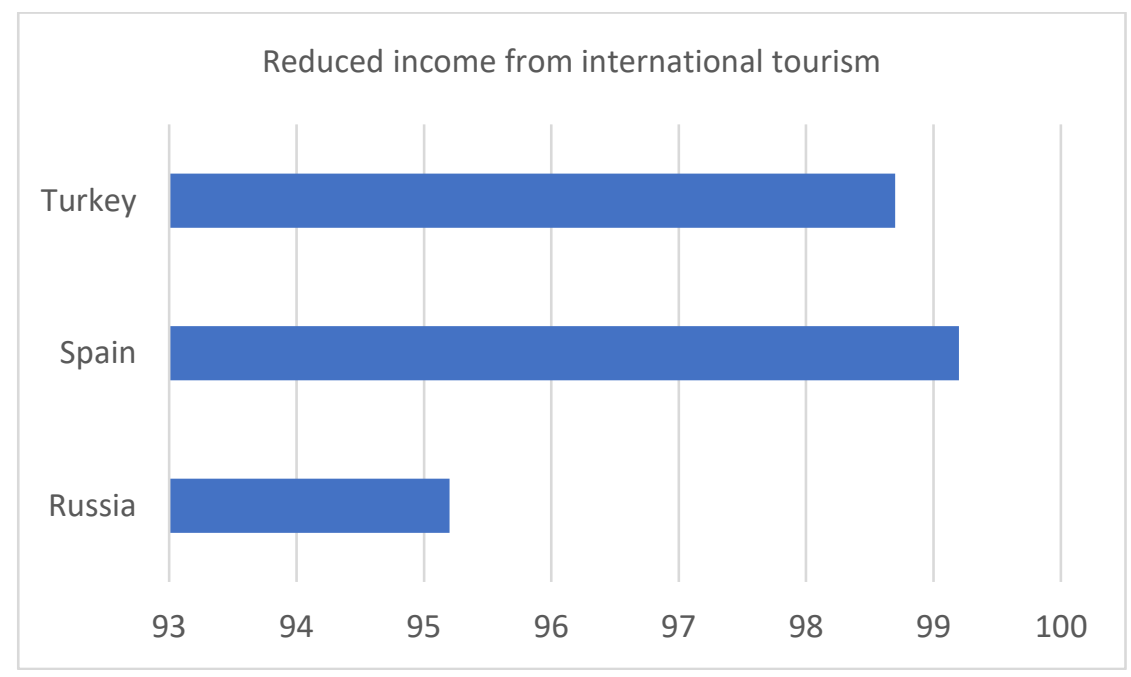

Figure 2. Reduced tourism income in Spain, Turkey and Russia (Rosstat Statistical Bulletin for the World Tourism Day 2020. https://www.cci.lt/wpcontent/uploads/2020/10) 
Figure 2 shows the revenues percentage reduction of international tourism in Spain, Turkey and Russia. As shown in figure 2, revenues from international tourism has decreased by $95.2 \%$ in Russia, 99.2\% in Spain, 98.7\% in Turkey (rosstat.gov.ru).

The total number of tourists, including domestic travel, stay in hotels, has decreased by $87.9 \%$ in Russia, $99.2 \%$ in Belgium, $95.7 \%$ in Spain, 92,9\% in Portugal. European countries have always attracted a lots of tourists. Therefore, the closure of borders, people's fear of Covid-19 infection, led to the fact that tourist flows disappeared.

The main factors in the sustainable development of the tourism business in Russia are: the opening of new tourist destinations, their transport accessibility, improvement of the citizens well-being and increasing interest in direct impressions from visiting new places (rosstat.gov.ru). People are becoming free to choose destinations for recreation, information support for hotel reservations is increasing, and state support projects for domestic tourism development are being implemented.

\section{Literature review / Research Background}

Forecasting of the Covid-19 pandemic impact on the tourism sector faces a high degree of uncertainty and a rapidly changing epidemiological situation at the level of states and regions ( $Y u$ 2021, p. 1668). In 2020, there was a model of tourism development in the context of an epidemic outbreak, however, this model requires constant updating (Yang, Zhang, Chen 2020). Europe has the first place in the world ranking of tourist destinations. The study of the European countries was focused on the hotel owners' opinion about measures for restoring the travelers trust and the new tourism destinations formation after the Covid-19 pandemic (Volkmann et al. 2021, p. 163).

The impact of the covid-19 pandemic on maritime tourism in Malaysia between January and the end of July 2020 was examined by Menhat et al. (2021) with predictions about the difficulty of restoring maritime tourism. Research on the relationship between risk-taking and the desire to travel has shown that stress levels are the deterrent. Social risk has the greatest impact. Financial risk is not so important (Falahuddin et al. 2020, p. 17). A study of changes in the tourism industry in Quebec (Canada) indicates that tourism in the long term can ensure the sustainability of the development of the region (Lapointe 2020, p. 635). In Lapland, where tourism is a strategically important sector of the economy, focus on regional tourism in the peripheral areas was studied using the example of the city of Kemi. It was recommended to strengthen the image of the city and develop its infrastructure. The tourism development in the city helps attract new investments, create new jobs, which contributes to the economic recovery (Ianioglo, Rissanen 2020, p. 523).

In connection with the tourism business sustainability, it is interesting to study the opinions of the restaurant owners as representatives of the accompanying business owners about new strategies that they will apply after the Covid-19 pandemic. The government support and strategies for tourism places availability development were identified as priorities in the restaurant business after the pandemic (Madeira, Palrão, Mendes 2021, p. 7). Research of the impact of the 
pandemic on the tourism business shows that the tourism industry must look for new ways to attract customers, use the opportunities of digital technologies and offer a tourist product in a new format that is interesting for consumers.

\section{Methodology}

The main objective of the study was to identify the potential of domestic tourism to ensure the development of the national tourism industry in the difficult economic conditions after the Covid-19 pandemic. To achieve this goal, we used comparative, descriptive and statistical methods of research, as well as the method of analyzing scientific literature. The information for the study is obtained from the reports of the Official Statistics Service of the Russian Federation. Moreover, the study used data from legislative acts of the Russian Federation and the Russian Public Opinion Research Center (VCIOM) data of opinion polls on the development of the tourism industry. The statistical data were analyzed, which allowed us to draw conclusions that correspond to the tasks set.

\section{Results}

A sociological survey conducted in Russia allowed us to identify the most popular destinations for domestic tourism. The main tourist destinations were associated with visiting the Russian capital Moscow and summer vacation destinations on seaside. The desire of tourists was more associated with holidays in sunny, warm regions with seaside and cities with the rich cultural and historical heritage (ekec.ru). As a perspective for the development of domestic tourism, we can note the fact that Russian citizens have shown interest in small cities in the European part of Russia, where monuments of cultural and religious heritage are concentrated. Figure 3 shows the most popular small cultural centers among tourists.

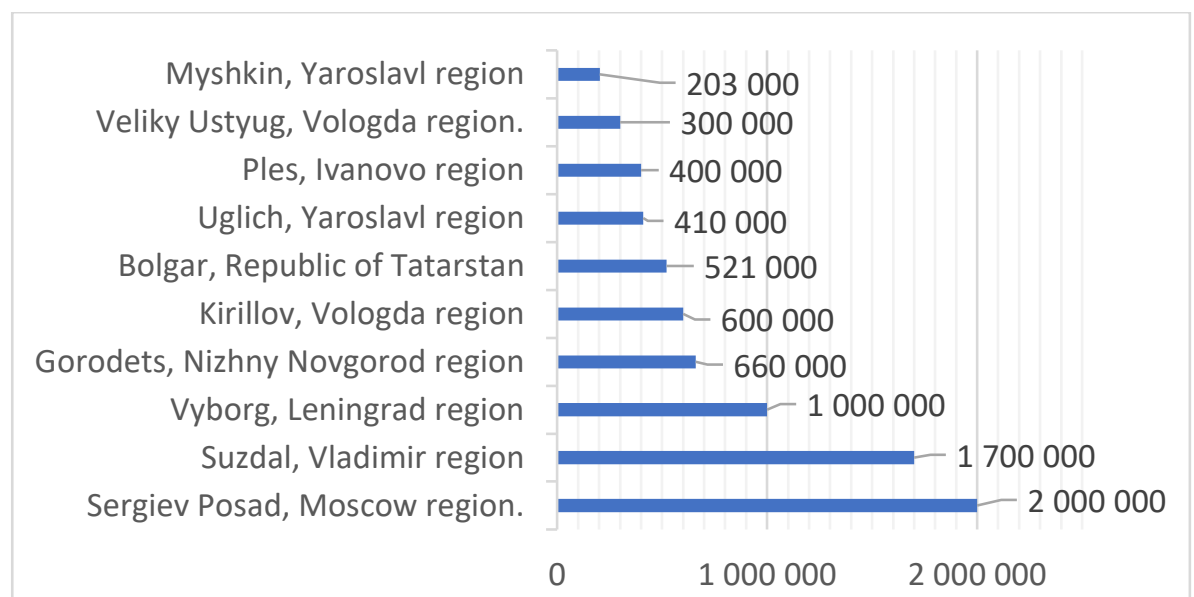

Figure 3. Small towns popular with tourists in the European part of Russia (Tourism statistics. Turazbuka NEWS ${ }^{\mathrm{TM}}$ (ekec.ru), https://ekec.ru/statistika ) 
The results of a survey of players in the Russian tourism market showed that beach and health tourism is returning to pre-crisis indicators. At the same time, the recovery of business tourism may be hampered by a number of factors, including the development of digital technologies. Experts in the tourism sector have identified several areas that will develop after the crisis associated with the Covid-19 pandemic. They are eco-tourism, sports, cultural, educational and children's tourism.

\section{Discussion}

The development of domestic tourism in Russia may face a number of difficulties. The most important is the problem of tourist accommodation, which ensures the safety of living (ekec.ru). $10 \%$ of the Russian hotel fund has no service standards or category. Table 1 shows the percentage of hotels by region that do not have a category nor international service standards.

Table 1. Percentage of hotels without a category (Tourism statistics. Turazbuka NEWS ${ }^{\mathrm{TM}}$ (ekec.ru), https://ekec.ru/statistika)

\begin{tabular}{|l|l|}
\hline Region & Percentage of hotels without a category \\
\hline Northern & 7 \\
\hline North-West & 3 \\
\hline Central & 13 \\
\hline Volgo-Vyatsky & 6 \\
\hline Central Black Earth Region & 3 \\
\hline Volga Region & 12 \\
\hline North-Caucasian & 10 \\
\hline Uralsky & 14 \\
\hline West Siberian & 12 \\
\hline East Siberian Far & 10 \\
\hline Eastern & 8 \\
\hline Kaliningrad region & 1 \\
\hline
\end{tabular}

The accommodation facilities in the rural areas are not enough for the development of ecological, village and sports tourism: $71 \%$ of hotels are urban and only $29 \%$ are located in country areas. (ekec.ru). The second problem is the positioning and promotion of new tourist destinations for domestic tourism. The third problem is the insufficient use of digital technologies in customer service, feedback, and constant interaction with customers (Desfonteines, Korchagina, 2019, p.10307). Finally, we have to mention that the assortment and quality of tours are often similar and not attractive for consumers. It can be concluded that in the context of the development of domestic tourism, consumers will strive to explore new areas. The most interesting are the historical facts about small towns that are not known to society. 


\section{Conclusion}

An analysis of the recovery of tourism in Russia after the covid-19 pandemic allows us to draw the following conclusions:

- the prospects for the domestic tourism development are associated with small cities in the European part of Russia, where monuments of cultural and religious heritage are concentrated;

- new tourist destinations development should include advantages of rural and sports areas with healthy lifestyles;

- the digital technologies implementation helps to advertise new destinations and constant contact with tourists;

- the attention should be paid to the hotel fund development in the regions and rural areas.

The development of domestic tourism in Russia is a positive factor for the new vectors formation of The Russian regional development and modern strategy for expanding additional values and services in accordance with the needs of modern travelers.

\section{References}

1. Rosstat News (rosstat.gov.ru) https://rosstat.gov.ru/folder/313/document/100185 (access date: 15-april-2021).

2. Volkmann, C. Tokarski, K.O., Dincă, V.M. Bogdan, A. (2021), Impactul Covid-19 asupra turismului din românia. studiu de caz exploratoriu asupra regiunii valea prahovei, „Amfiteatru Economic”, V. 23, I. 56, pp. 163-163, DOI: 10.24818/EA/2021/56/196

3. Menhat, M., Mohd Zaideen, I.M., Yusuf, Y.b, Salleh, N.H.M., Zamri, M.A., Jeevan, J. (2021), The impact of Covid-19 pandemic: A review on maritime sectors in Malaysia (Review). „Ocean and Coastal Management", V. 209, 1, DOI: 10.1016/j.ocecoaman.2021.105638.

4. Yu., S.I. (2021), Implementation of strategies to counteract the consequences of the pandemic in the tourism sector, „,Turkish Journal of Computer and Mathematics Education ”, 12 (4), pp. 1667-1675. DOI: 10.17762/turcomat.v12i4.1421.

5. Yang, Y., Zhang, H., Chen, X. (2020), Coronavirus pandemic and tourism: Dynamic stochastic general equilibrium modelling of infectious disease outbreak, „Annals of Tourism Research ”, V.83, № 102913, DOI: 10.1016/j.annals.2020.102913.

6. Madeira, A., Palrão, T., Mendes, A.S. (2021), The impact of pandemic crisis on the restaurant business, 13 (1), № 40, pp. 1-13, Sustainability, Switzerland, DOI: 10.3390/su13010040.

7. Falahuddin, A.F., Tergu, C.T., Brollo, R., Nanda, R.O. (2020), Post COVID-19 pandemic international travel: Does risk perception and stress-level affect future travel intention?, „Jurnal Ilmu Sosial dan Ilmu Politik ”, 24 (1), pp. 1-14, DOI: 10.22146/JSP.56252.

8. Lapointe, D. (2020), Reconnecting tourism after COVID-19: the paradox of alterity in tourism areas, „Tourism Geographies ”, 22 (3), pp. 633-638. DOI: 10.1080/14616688.2020.1762115.

9. Ianioglo, A., Rissanen, M. (2020), Global trends and tourism development in peripheral areas, „Scandinavian Journal of Hospitality and Tourism”, 20 (5), pp. 520-539. DOI: $10.1080 / 15022250.2020 .1848620$.

10. Tourism statistics. Turazbuka NEWS ${ }^{\mathrm{TM}}$ (ekec.ru), https://ekec.ru/statistika/ (access date: 15april-2021).

Desfonteines, L., Korchagina, E. (2019), Competences of Managers and Specialists of Industrial Enterprises, „Vision 2025: education excellence and management of innovations through sustainable economic competitive advantage", pp. 10305-10314. 